\title{
Preparing Pre-Service Teachers to Teach in Rural Schools
}

\author{
Dr. P.J.H.Heeralal \\ Senior Lecturer, University of South Africa, College of Education \\ P.O.Box 392, Unisarand, South Africa, 0003 \\ Email: Heerapjl@unisa.ac.za
}

\section{Doi:10.5901/mjss.2014.v5n20p1795}

\begin{abstract}
Teacher training institutions, have to date, paid little or no attention to train teachers to teach in rural schools. This paper examines what needs to be done by teacher training institutions in South Africa to address the issue. Pre-service teachers following the Bachelor of Education programme at a South African university were interviewed to ascertain what needs to be done in order to address the professional needs of pre-service teachers to teach in rural schools? The data indicated that preservice teacher were not given the opportunity to be exposed to teaching in rural schools during their teaching practice and the curriculum content of the Bachelor of Education degree did not include aspects that relate to aspects of rural teaching, making it difficult for rural schools to retain teachers. Based on the findings the following recommendations are made: modules that have a specific focus on teaching in rural schools be included in the curriculum and that every student is required to spend at least one practice teaching session in the course of the Bachelor of Education programme in a rural school. Education faculties must ensure that they have staff members who have experience in teaching at rural schools to teach the modules that relate to rural teaching. It is also recommended that incentives be offered to teachers who teach in rural schools.
\end{abstract}

Keywords: rural schools, teacher education, teaching experience.

\section{Introduction}

The term 'rural', according to Baills \& Ross (2001) in Lingam (2012), in most educational contexts lacks a common and explicit definition. Generally, the three key characteristics of rural schools are isolation, distance and smallness (Bray, 1987). However, one common factor highlighted by various researchers about rural schools is their remoteness from main centres and this poses a lot of challenges to teachers (Bray, 1987).A large proportion of students that train to become teachers come from rural areas. Many of the universities in South Africa that train these teachers are located in urban centers. Teaching practice that student teachers undergo happens either at urban or in township schools. Few students, if any, do their teaching practice in rural schools. Hence student teachers receive very little or no training to teach in rural schools. Yet, it is in these schools, that there is the greatest need for teachers. This paper addresses some of the challenges that rural schools face and the issues that need to be considered in the training of teachers to teach effectively in a rural school. Teachers with little knowledge and skills of teaching in rural contexts, are likely to adversely impact the education of rural children who are already at risk. For effective teaching practices in rural schools, teachers need adequate professional preparation during their initial teacher education program and also on-going education and training whilst they are in service. As often highlighted, teachers with good professional preparation are a catalyst not only for the provision of quality education for all children but also in terms of national development (Chandra, 1994; UNESCO,1995).

\section{Literature Review}

International literature on training programs to accommodate teaching in rural schools presents a gloomy picture (Little, 2001). The same applies to the situation in South Africa. As a result of professional differences associated with work in rural schools, adequate professional preparation is needed to enable teachers to effectively work in rural setting (Lingam, 2012). Apart from the educational characteristics, rural schools pose other challenges to teachers such as the 'cultural gap' (Thaman, 2002). Teachers who teach in rural schools will thus encounter diverse cultural backgrounds of children not only in urban classrooms but also in rural classrooms and this necessitates multicultural studies in the teacher education programmes. Teachers need to be literate and sensitive to other cultures in order to cope with teaching and learning culturally and linguistically diverse backgrounds of students (Lingam, 2012). 
In order to put in perspective why teacher training institutions need to prepare teachers to teach in rural schools, the challenges that rural school face need to be understood. Some of the challenges that rural schools face will be discussed. These include the following:

\subsection{Attracting good quality teachers to fill vacant posts}

According to Collins (1999:1) the principal reason why teachers leave rural areas is isolation - social, cultural and professional. Thus, to attract good quality teachers, schools must target candidates with a rural background or those who have personal characteristics that predisposes them to live in rural areas. Students that have a rural background should therefore be encouraged to consider returning to their rural home communities once they qualify. They should be provided with incentives to return to teach in rural schools, if not in their own communities.

\subsection{Retaining teachers at the schools}

Once qualified teachers have been recruited, the challenge is to retain then at a school. The degree to which a rural teacher becomes involved in community, educational and cultural programs influences his or her decision to remain at a rural school. Therefore retention requires a co-ordinated school-community effort that assists the new rural teacher overcome feelings of isolation, acquire a sense of community security, and develop professional competence.(Collins, 1999: 2). Providing the teacher with emotional support and good mentoring can also assist in increasing retention rates significantly.

\subsection{Housing and transport}

Housing in rural areas does not meet the standards and expectations of the rural teacher. Often suitable housing is located far away from the school. The teacher has thus to commute long distances to school using public transport. The public transport system in rural areas is underdeveloped and unreliable. Sub-standard school facilities and accommodation together with the poor socio-economic background of many rural communities are additional challenges highlighted in the international literature (Lingam, 2012). Besides possessing relevant teaching qualifications, being aware of the realities of rural life would help a teacher to appreciate the difficult situation in rural schools and thereby use suitable practical strategies to ensure children achieve optimum learning outcomes (Eppley, 2009).

\subsection{Resources}

Rural school are often under resourced, both in human and physical resources. There is an inadequate supply of textbooks, stationary, library materials, laboratory equipment and other teaching aids. Classroom space is either in short supply or the infrastructure is very poor. Toilet facilities are very poor and sports equipment and facilities are not available.

The preceding literature describes some alarming trends relating to the training of teachers to teach in rural schools. What emerges that is that teachers working in rural schools encounter difficulties as well as challenges due to lack of professional preparation during teacher training. Considering the above, it is vital that pre-service and in-service teacher education programs professionally prepare teachers to work effectively not only in urban schools but also in rural schools (Lingam, 2012)

\section{Purpose of the Research}

The purpose of the study was to investigate the professional preparation of teachers at the pre-service level for work in rural primary schools. The study was guided by a central research question: What needs to be done in order to address the professional needs of pre-service teachers to teach in rural schools?

\section{Rationale for Study}

Teachers are prepared each year for teaching without the benefit of any informed research into their professional preparation to teach in rural schools. As such the findings of the present study could provide better insights about teacher preparation for rural education 
Although this is a small-scale study, the findings may help inform the practices of those responsible for teacher education in South Africa about the strengths and limitations of the training program to cope with work and life in rural settings. It is only through research findings that necessary improvements and developments in teacher education could be made.

For academics responsible for the Bachelor of Education degree programs at Universities in South Africa, the findings would help inform their professional practice, in terms of what needs to be done to better equip pre-service teachers to teach in schools especially those located in rural settings.

\section{Methodology}

A qualitative case study design was employed for the study (Yin, 1984). A purposive sampling technique was used for the study. In accordance with the qualitative nature of the research, the data gathering method employed was interviews (Merriam, 1999). In selecting the sample size, 15 pre-services teachers registered for the Bachelor of Education degree at the university were chosen. Consent was obtained from the pre-service teachers to have the interviews tape recorded. The tape recorded interviews were later transcribed and this ensured constant reference of the data.

The qualitative data that was collected were analysed according to the themes and patterns which emerged as a result of a process of inductive categorization (Bogdan \& Biklen, 1992; Patton, 1990). The data was then interpreted in relation to the existing literature to answer the research question posed. The use of quotes from the interview data are presented because, as Ruddock (1993: 19) has indicated that they carry "a rich density of meaning in a few words" and in this case about the pre-service teacher education program for teaching in rural schools.

\section{Findings and Discussion}

In order to prepare teachers to teach in rural schools, teacher training institutions need to address the following key issues:

\subsection{Exposure of student teachers to rural schools during teaching practice.}

Data collected from a random sample of final year full time Bachelor of Education students at a university in South Africa indicate that seventy four pecent (74\%) of students have had no exposure to rural schools during their teacher training. Sixty seven percent 74 (67\%) of these students, if given the opportunity, would like to or prefer to teach in rural schools in South Africa. The challenge for teacher training institutions is therefore to find ways and means to expose these preservice teachers to rural schools during teacher training. Exposure of the students to rural schools will give them an opportunity to experience, first hand, the conditions under which teachers teach in rural schools. Under guidance of mentor teachers and experienced lecturing staff, students will get an insight into teaching in a rural school. If the experience gained is meaningful to the student, the data of the above survey indicates that students are prepared to take up the challenge of teaching at rural schools. In the survey, when asked to give reasons why they would like to teach in rural schools, students responded by saying the following:

\footnotetext{
"to uplift the standard of education in the place I grew up, I relate better to the conditions there"

"to give back to my community"

"I feel that there are so many opportunities and the learners are so willing to learn and grateful for everything you do"

"the gap between urban and rural schools need to be bridged"
}

It is therefore imperative that teacher training institutions explore viable ways of exposing pre-service teachers to gain experience in teaching at rural schools. This can be achieved by reviewing the teacher education curriculum and including modules that focus on rural education. Further, pre-service teachers need to be exposed to teaching in rural school during their practice teaching modules.

\subsection{Curriculum issues}

The curriculum of teacher training courses needs to be reviewed in order to include content that relate to and are relevant to rural issues and dynamics of life in rural communities (Barely \& Brigham, 2008:3). Pre-service teachers indicated that the present curriculum for the Bachelor of Education degree does not include and modules relating specifically to 
teaching in rural schools.

\subsection{Recruiting student teachers from rural areas}

Monk (2007) suggests a "grow your own" strategy, where teacher training programs recruit prospective teachers from rural areas, and in some cases make arrangements to allow them to stay in their area while they pursue their education. Boyd et al. (2007 : 127) found that proximity to home matters because new teachers seek positions if not at home, at least in regions "similar to those where they grew up."

\subsection{Staffing of education faculties}

In preparing pre-service teachers to teach in rural schools, institutions need to pay special attention to staffing of education faculties. Staff need, in addition to relevant academic qualifications, have extensive teaching experience and expertise in a school environment and in particular rural schools. Without adequate practical experience in teaching (including teaching in rural schools), it is the view of the researcher, that academic staff in faculties of education would not be able to expose and train pre-service teachers to teach in rural schools In order to train students to be effective in rural, schools this matter must be given serious consideration by higher education authorities..

\subsection{Internship for teachers}

Since there is a shortage of teachers, especially in rural schools, considerations should be given to the introduction of an internship for newly qualified teachers. The internship will require newly qualified teachers to teach in rural schools, under the supervision of a mentor teacher for a reasonable period of time, preferably one year. Should the teacher prefer to continue teaching in the area, he/she should be offered a post, if a vacancy exists.

\subsection{Implementation of rural allowances for teachers}

Implementation of a rural allowance system, similar to the one offered to the medical profession, would also serve to attract and possibly retain teachers in rural schools. Although the rural allowance scheme was approved by education authorities in South Africa, it has not been implemented to date.

\section{Recommendations}

Based on the findings the following recommendations are made: during the process of curriculum review at universities attention should be given to including modules that have a specific focus on teaching in rural schools and that every student be required to spend at least one practice teaching session in the course of the Bachelor of Education programme in a rural school. Education faculties must ensure that they have staff members who have experience in teaching at rural schools to teach the modules that relate to rural teaching. It is also recommended that incentives be offered to teachers who teach in rural schools.

\section{Conclusion}

Rural educators have long been calling for special preparation for new teachers to teach in rural schools (Barely \& Brigham, 2008:3). Wilson, Floden and Ferrini-Mundy (2001) suggest that there has been limited research on preparing teachers to work and stay in rural communities. Some possibilities have been explored in this article, and with further research, specialized courses could be developed to address the issue of preparing teachers to teach in rural schools.

\section{References}

Chandra, R. (1994). Pacific teacher needs strengthened. The University of the South Pacific Bulletin, 27(13), 1-2.

Baills, L. \& Rossi, T. (2001). The transition from isolated, rural contexts to boarding school-Can school physical education and sport play a part? Journal of Physical Education New Zealand 34(1), 40-52.

Barley, Z.A. \& Brigham, N. (2008). Preparing teachers to teach in rural schools. Washington, DC U.S. Department of Education.

Bray, M. (1992). Education planning in small countries. University of Hong Kong, Hong Kong: UNESCO. 
Bogdan RC \& Biklen SK, 1992; Qualitative Research for Education; an introduction to theory and methods: Allyn \& Bacon.

Boyd, D., Lankford, H., Loeb, S. \& Wyckoff, J. (2005). The draw of home: How teachers' preferences for proximity disadvantage urban schools. Journal of Policy Analysis and Management, 24(1), 113-132.

Burns, R. B. (1996). Introduction to research methods. Chicago: Longman.

Collins, T.(1999). Attracting and retaining teachers in rural areas: ERIC Digest. www.ericdigestests.org/2000-4/rural.hmt. Accessed: 10 October 2008.

Eppley, K. (2009). Rural schools and the highly qualified teacher provision of no child left behind: A critical analysis. Journal of Research in Rural Education, 24(4), 1-11.

Lingam G.I. (2002), Preparing teachers for rural schools: An empirical evidence from a Fiji case, Greener Journal of Educational Research, Vol. 2 (2).

Little, A. (2001). Multi-grade teaching: Towards an international research and policy agenda. International Journal of Educational Development. 21(6), 481-497.

Merriam, S.B. (1998), Qualitative research and case study applications in education, Jossey-Bass Publishers San Francisco.

Monk,D.H. (2007). Recruiting and retaining high-quality teachers in rural areas. The Future of Children, 17(1), 155-174.

Patton, M.Q. (1999). Enhancing the quality and credibility of qualitative analysis. Health Services Research, 34(5): 1189-1208.

Ruddock, J. (1993), The theatre of daylight: Qualitative research and school profile studies. In M. Schratz (ed.) Qualitative voices in educational research. London. Falmer.

Thaman, K. H. (1989). Ako and faiko: Cultural values, educational ideas and teacher role perceptions in Tonga. Unpublished PhD thesis: The University of the South Pacific, Suva, Fiji.

UNESCO,(1995). Debate on educational policy 1993: Reflections and proposals. Paris: UNESCO.

Wilson,S., Floden.R. \& Ferrini-Mundy,J. (2001) Teacher preparation Research: Current knowledge gaps and recommendations. Seattle: University of Washington.

Yin, R.K (1984). Case method; Social sciences; Research, Sage Publications: Beverly Hills, California. 